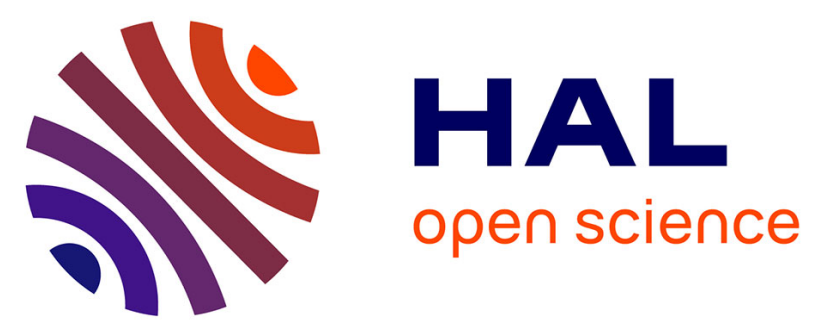

\title{
A transnational comparative study of preservice teachers' critical thinking skills and metaliteracy self-efficacy
}

Florent Michelot, Sébastien Béland, Bruno Poellhuber

\section{- To cite this version:}

Florent Michelot, Sébastien Béland, Bruno Poellhuber. A transnational comparative study of preservice teachers' critical thinking skills and metaliteracy self-efficacy. Higher Education, Skills and Work-Based Learning, 2022, ahead-of-print (ahead-of-print), 10.1108/HESWBL-10-2021-0191 . hal03555339

\author{
HAL Id: hal-03555339 \\ https://hal.science/hal-03555339
}

Submitted on 5 Feb 2022

HAL is a multi-disciplinary open access archive for the deposit and dissemination of scientific research documents, whether they are published or not. The documents may come from teaching and research institutions in France or abroad, or from public or private research centers.
L'archive ouverte pluridisciplinaire $\mathbf{H A L}$, est destinée au dépôt et à la diffusion de documents scientifiques de niveau recherche, publiés ou non, émanant des établissements d'enseignement et de recherche français ou étrangers, des laboratoires publics ou privés.

\section{(ㄷ)(1) $\$$}

Distributed under a Creative Commons Attribution - NonCommerciall 4.0 International 


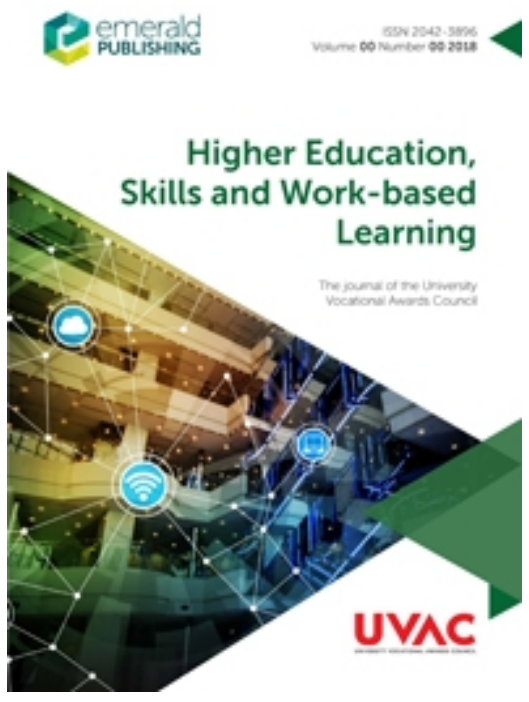

\section{A transnational comparative study of preservice teachers' critical thinking skills and metaliteracy self-efficacy}

\begin{tabular}{|r|l|}
\hline Journal: & Higher Education, Skills and Work-Based Learning \\
\hline Manuscript ID & HESWBL-10-2021-0191.R1 \\
\hline Manuscript Type: & Research Paper \\
\hline Keywords: & $\begin{array}{l}\text { Critical thinking, Information literacy, Teacher education, Cross-cultural } \\
\text { teaching and learning }\end{array}$ \\
\hline \multicolumn{2}{|l}{} \\
\hline
\end{tabular}

\section{SCHOLARONE ${ }^{\text {IM }}$ Manuscripts}

Emerald allows authors to deposit their AAM under the Creative Commons Attribution Non-commercial International Licence 4.0 (CC BY-NC 4.0). To do this, the deposit must clearly state that the AAM is deposited under this licence and that any reuse is allowed in accordance with the terms outlined by the licence. To reuse the AAM for commercial purposes, permission should be sought by contacting permissions@emeraldinsight.com.

For the sake of clarity, commercial usage would be considered as, but not limited to:

- Copying or downloading AAMs for further distribution for a fee;

- Any use of the AAM in conjunction with advertising;

- Any use of the AAM by for promotional purposes by for-profit organisations;

- Any use that would confer monetary reward, commercial gain or commercial exploitation.

Emerald appreciates that some authors may not wish to use the CC BY-NC licence; in this case, you should deposit the AAM and include the copyright line of the published article. Should you have any questions about our licensing policies, please contact permissions@emeraldinsight.com. 


\title{
A transnational comparative study of preservice teachers' critical thinking skills and metaliteracy self- efficacy
}

\begin{abstract}
Purpose. While training students to new literacy and critical thinking has been recognized for several decades, it seems even more crucial today as education is presented as a lever to fight against fake news. Preservice teachers, both so-called digital natives at the cutting edge of the social web and tomorrow's educators, represent a useful object of study.

Methodology. Using a quantitative methodology, this article is part of sequential mixed design research aiming to describe the level of preservice teachers' $(n=245)$ critical thinking in three French-speaking nations: Wallonia, France, and Quebec. We aimed to see to what extent critical thinking skills (measured with a translated version of the Halpern Critical Thinking Assessment; Halpern, 2016) can notably be influenced by metaliteracy self-efficacy. Metaliteracy is a concept that aims to join information, digital, and media literacy providing a comprehensive framework "for engaging with individuals and ideas in digital environments" (Mackey and Jacobson, 2011, p. 70).

Findings. We establish the influence of individual determinants such as the feelings of self-efficacy in metaliteracy as well as the belief in the likelihood of becoming a teacher. We propose a model predicting the critical thinking skills based on selfefficacy in critical thinking and metaliteracy, the type of training, and the interaction between employment and the country of study.

Originality. Considering contemporary information issues and infodemic phenomena, critical thinking skills should be developed among preservice teachers. There is a significant positive correlation between metaliteracy self-efficacy and critical thinking skills. Pre-service teachers' country of study, as well as their training trajectory, seems to influence their critical thinking skills. Involvement in professional life also appears to promote critical thinking skills.
\end{abstract}

\section{Keywords}

critical thinking skills; information literacy; digital literacy; teacher training

\section{Introduction}

We live in a time of ever-accelerating social mediation of information where traditional intermediaries are gradually replaced by apomediaries, which are resources or individuals guiding consumers to trustworthy information or contributing to enhancing the credibility of information (Eysenbach, 2007) With the contemporary overabundance of information, we might assume that better-informed students would be better trained. This is why critical thinking and literacies (information literacy, digital literacy, etc.) are widely considered as 21 st-century skills (van Laar et al., 2017), valued in and out of the educational context. However, students can be impaired in their ability to distinguish fake news or to identify underlying intentions (Flood, 2015). Of course, teachers' relation to information is impacted by the digital revolution. For example, teachers are on the front lines to deconstruct conspiracy theories in their classrooms. In the pandemic context of "infodemia" and disinformation, the issue of information literacy and critical thinking skills becomes all the more relevant for education professionals (Puig et al., 2021). If the level of study or profession doesn't 
entirely prevent beliefs, education is probably one of the keys to address the issue. For example, it seems that people with higher education levels are less likely to believe in conspiracy theories (van Prooijen, 2017) and critical thinking is a way to help students to avoid non-empirical messages (Blair, 2012).

Many subskills are interrelated between information literacy and critical thinking (Desfriches Doria, 2018). This is particularly true with metaliteracy, an emerging conceptualization of literacies. It inspired the recent Quebec Digital Competency Framework (Ministère de l'Éducation et de l'Enseignement supérieur, 2019) and has been partially remobilized in recent ACRL (2016) framework. The latter strengthens the central idea of metaliteracy which encompasses critical self-reflection (Mohamed, 2019). Critical thinking can be defined, among various definitions, as "the propensity and skill to engage in an activity with reflective scepticism” (McPeck, 1981, p. 8).

During the last two decades, learners' information literacy has been studied in Wallonia (Belgium) and Quebec, as well as in France with similar methodology. Results obtained seem to attest that many undergraduate students have weak knowledge of the basic elements of the information search process in traditional environments (Pochet, 2016). Also, a meta-analysis seems to confirm that following vocational training (VT) has a positive impact on critical thinking skills and dispositions (Fong et al., 2017). Considering the previous research between these three nations and the fact that the latter have specific teacher training programs (disciplinary or vocational training), it seems useful to extend the comparative study by adopting a renewed conceptual basement.

\section{Literature Review}

\section{About Critical Thinking}

Critical thinking is the subject of a great variety of definitions, but we can consider that it "is good thinking that is well reasoned and well supported with evidence" (Butler and Halpern, 2020, p. 152): to that, it is purposeful, reasoned, and goal-directed (Halpern, 1998). There is an agreement around conceptual key elements, like judgment, reasoning, reflective thinking, and metacognition (Fischer, 2001), which are mobilized to achieve the desired result by thinking rationally and in a goal-oriented fashion (Butler, 2012).

Critical thinking can be characterized by a set of skills that are: i) verbal reasoning (e.g., recognizing rhetorical fallacies); ii) argument analysis (e.g., distinguishing between facts and opinions, identifying argumentation); iii) hypothesis testing (e.g., discussing on causality and explanations based on empirical information); iv) likelihood and uncertainty (e.g., evaluating odds and chances); v) decision-making and problem-solving (e.g., selecting decisions or behavior from among plausible choices) (Butler and Halpern, 2020).

Since having critical thinking skills does not necessarily lead to a critical thinking process, critical thinking is not only a list of skills: that is also dispositions to use those skills and strategies because it is important to be disposed to put them into practice when necessary (Butler and Halpern, 2020; Hitchcock, 2018). Dispositions are 
inclinations "to do something, given certain conditions" (Ennis, 1996). Therefore, contemporary theorization suggests understanding critical thinking as a set of skills and attitudes (Butler and Halpern, 2020). The Delphi Report model (Facione, 1990), identifies seven dispositions which are truth-seeking, open-mindedness, analyticity, systematicity, inquisitiveness, maturity of judgment, and critical thinking selfconfidence.

Ennis and Scott (2018) identified 38 tools to measure critical thinking. Moreover, only three of these tools quantifying critical thinking skills or dispositions are available in French. Two of them focus on skills (the Watson-Glaser Critical Thinking Appraisal; WGCT and the Cornell Critical Thinking Test; CCTT) and one on the dispositions (the California Critical Thinking Disposition Inventory; CCTDI). The French versions of these tools (the WGCTA and the CCTT) appear to be unstudied and are based on different models. The third tool identified in French, the CCTDI, is based on Delphi Report model dispositions. Despite the usefulness of this tool, its restricted access encourages the use of another measuring tool and the choice of a more parsimonious approach that will allow us to discuss the effect of self-efficacy.

\section{Metaliteracy and Critical Thinking}

Critical thinking and information literacy (particularly content evaluation literacy) have overlapping conceptions (Hollis, 2019), suggesting some integration between literacy and critical thinking. Since the 2000 s we see a conceptual reconstruction of literacies that echoes the lowering media boundaries enabled by ICT. For example, the latest ACRL (2016) framework suggests that maintaining an open mind and a critical stance is an ability to address research as an inquiry. Thus, the concept of Metaliteracy "is envisioned as [...] model for information literacy to advance critical thinking and reflection in social media" (Jacobson and Mackey, 2013, p. 84) and fits our new information and media environments (Špiranec, 2014). This conceptual junction between critical thinking and reframed literacies are for the future on the educational level: first, it results in bringing closer new media contexts and critical thinking; secondly, it makes it possible to operationalize critical thinking through information, digital, or media literacies skills frameworks. The portrayal of the critical thinker as an "amiable skeptics that investigate claims, but also evaluate their own claims and attempt to overcome their own biases" (Butler and Halpern, 2020, p. 156) is consistent with the portrayal of the metaliterate learner "always challenging his or her own biases through metacognitive thinking" (Mackey, 2019, p. 1) and the information literate learner with a "skeptical stance and with a self-awareness of their own biases and worldview" (ACRL, 2016, p. 4).

Yet, there is an anticipated articulation between information literacy and critical thinking (Desfriches Doria, 2018; Hollis, 2019). In short, we support the idea that critical thinking "for evaluating information should now be considered a basic literacy" (Georgiadou et al., 2018, para. 1) and that's why metaliteracy offers a promising avenue to apprehend needed skills in the social-networks age. The concept is consistent with recent rapprochements between information, digital, media, or visual literacies. Four goals are suggested for learners: i) actively evaluate content while also evaluating one's own biases; ii) engage with all intellectual property, ethically and responsibly; iii) produce and share information on collaborative and participatory environments; iv) develop learning strategies to meet lifelong personal and professional goals (Mackey 
and Jacobson, 2018). Learning objectives are linked to behavioral (what someone should be able to do), affective (learners' emotions or attitudes), cognitive (what students should know), and metacognitive (what learners think about their thinking) engagement with information and information ecosystem. Alongside learning objectives that echo the current evolving information ecosystem, "traditional" information literate skills can be linked to the so-called conceptual core of information literacy defined by Špiranec (2014), i.e., finding, evaluating, using, or communicating information. Metaliteracy gives an important role to metacognitive and self-reflective skills in an increasingly complex information environment (Marzal and MartínezCardama, 2020)

Although little has been said on the subject, self-efficacy has a direct influence on information literacy in the same way that self-confidence is a part of critical thinking dispositions and influences critical thinking skills. Furthermore, if all new literacies (especially metaliteracy) are considered as interlinked with critical thinking, then one can assume that the self-efficacy for evaluating elements will influence critical thinking. A strong self-efficacy perception is essential for self-regulation, but also information literacy development throughout life (Kurbanoglu, 2003): ICT regular use and information literacy are positively correlated to ICT self-efficacy perception. For example, students with high levels of self-efficacy have a higher propensity to use library databases than students with low levels of information literacy (Tang and Tseng, 2013). Kurbanoglu et al. (2006) developed a scale to measure self-efficacy relating to traditional information literacy. The validity and fidelity indices established during the exploratory factor analysis of this "ILSE" scale are conclusive. More recently, Sommer $\&$ al (2021) displayed an adequate fit with the observed data by confirmatory factor analysis. Nevertheless, there is no self-efficacy scale considering conceptual evolution related to literacies and we believe that the development of instruments that respond to conceptual and societal changes is essential. That's why we developed and validated a self-efficacy scale based on partial metaliteracy goals and objectives (Author 1, 2020; cf. 4.3).

\section{Research Questions}

The research aimed to describe preservice teachers' critical thinking skills scores notably regarding environmental factors (training type, country of study, employment) and personal determinants (metaliteracy self-efficacy, belief in the likelihood to become a teacher) in three French-speaking nations (Wallonia, France, and Quebec).

The two research questions (RQ) were: $R Q_{i}$ ) what is the critical thinking skill level of $1^{\text {st }}$-year preservice teachers and how do they perceive and evaluate their metaliteracy skills?; $\mathrm{RQ}_{\mathrm{ii}}$ ) is Metaliteracy self-efficacy a good predictor of critical thinking skills or is the potential gap among preservice teachers the fruit of other characteristics?

\section{Methodology}

\section{Background}


This article is part of broader research conducted in Wallonia (French-speaking region of Belgium), France, and Quebec (principal French-speaking part of Canada). We focused on preservice secondary school history teachers to ensure a certain homogeneity of the sample.

It is meaningful to examine future teachers' skills because they will be at the core of educational projects against fake news. Quebec and the French Community of Belgium have chosen vocational training from the beginning of university education for their preservice teachers. French Community of Belgium also offers teaching training at the second cycle of university: this approach, which is also favored in France, involves completing a baccalaureate program in a disciplinary specialization first. These three countries provide a useful field to compare the effect of vocational training (VT) versus disciplinary training (DT).

\section{Sample \& Participants}

Data collection took place in five establishments: one in France (Université Bordeaux-Montaigne), two in Quebec (Université de Montréal), and two in Wallonia (Université de Namur, and Henallux). This is a non-probabilistic convenience sample. The research sample is composed of preservice teachers entering higher education $\left(1^{\text {st }}\right.$ year) and believing in the likelihood to become a teacher history in secondary/high school. We selected 245 responses $(n=245)$ that met these criteria. We focused our study on 2 types of training: the $1^{\text {st }}$ one consists of preservice teachers in a postsecondary VT $(n=63)$; the $2^{\text {nd }}$ consists of preservice teachers in a post-secondary disciplinary training DT $(n=182)$. Quebec preservice teachers in VT must complete a bachelor's degree (BA) in Secondary Social Sciences Education. French preservice teachers are in DT: preservice teachers should first complete a BA in History, Art History or Archaeology before attending a graduate program in Education. Finally, in Wallonia, the 2 options are available: the $1^{\text {st }}$ alternative is to complete a "régendat" in Human Sciences Education like in Quebec (VT); the $2^{\text {nd }}$ alternative is to complete a disciplinary program (e.g., a BA in History, Art History or Archaeology) before entering a graduate program in Education like in France (DT). Figure 1 summarizes the structure of the sample by country of study and the type of training.

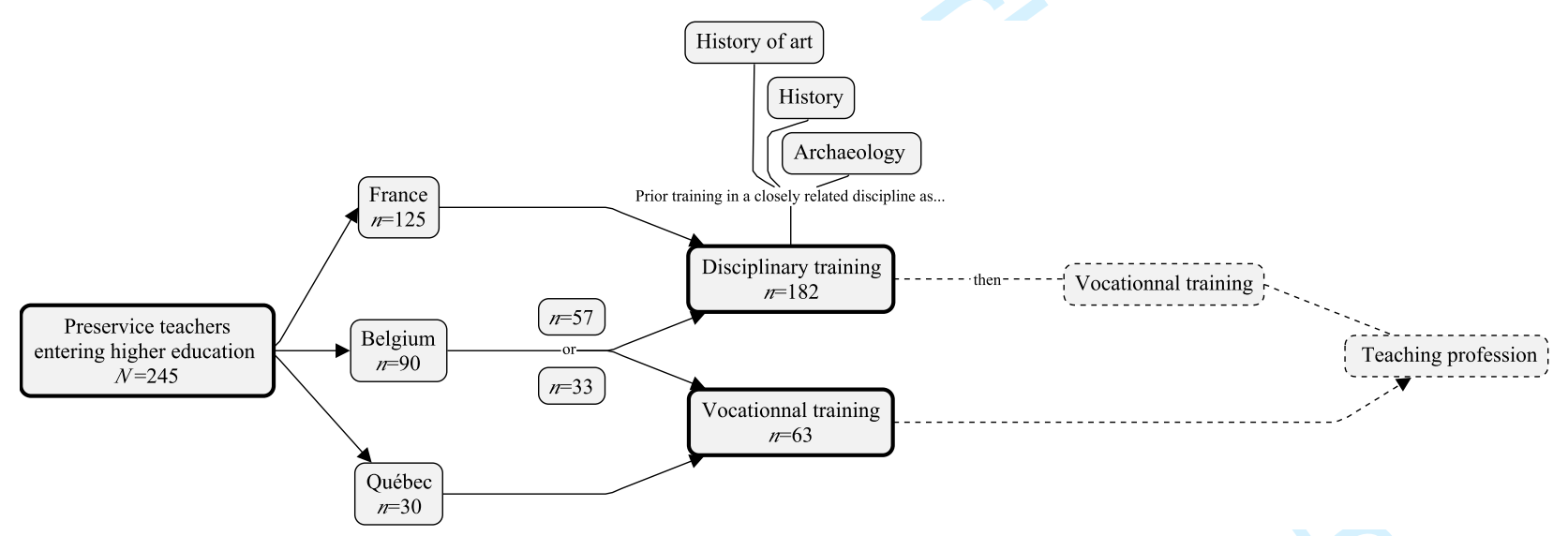

Figure 1. Structure of the sample by country of study and type of training. 


\section{Design and Instruments}

The Halpern Critical Thinking Assessment (HCTA) is one of the most recent critical thinking skills tests. It assesses a five-factor model that is taken from the abovementioned Halpern (1998) model. This test has two main versions: each of them is available in short (multiple-choice questions, MCQ) or long versions (open questions and MCQ). Compared to CCTT, HCTA is preferred by students and results show a good content validity (Verburgh et al., 2013). For the HCTA translation into French, we adopted the short version (with MCQ) and followed the cross-cultural validation method (Vallerand, 1989). The confirmatory factor analysis (CFA) suggests that once reduced to 10 items (instead of 20), the 5-factor model specified by the author who developed the scale display adequate fit with the observed data collected; reliability is acceptable to good, $\omega_{t}=.78$ et $\alpha=.66$ (Author 1 et al., 2021). This reduced version of the HCTA is called HBCTSS (HCTA Based Critical Thinking Skills Score).

Finally, metaliteracy self-efficacy (MASE) is a 16-item scale based on the thirty-two metaliteracy learning objectives (Mackey and Jacobson, 2018). Score reliability is excellent $(\alpha=.92, \omega=.92)$ and EFA supports the one-factor model proposal (Author 1, 2020). Respondents must rate on a scale of 1 to 10 ( $1=$ "Strongly disagree"; $10=$ "Strongly agree") what they feel they can do.

\section{Data Collection}

Data were collected between December 2018 and March 2019. Essentially, surveys were completed face-to-face, during a course, for students at the University of Bordeaux-Montaigne, the University of Montreal, the University of Namur, and Henallux at the Malonne site $(n=233)$. Marginally, surveys were completed remotely for students at UQAM and at Henallux in Bastogne $(n=12)$. In all cases, these were digital forms administered on the Internet within a 40-minute time frame.

\section{Analysis}

\section{Data preparation}

We used the $k$-nearest neighbors $(k \mathrm{NN})$ method which can be used regardless of the type of missing data (random or not). Data have been standardized ( $z$-score).

\section{Tests}

$\mathbf{R Q}_{\mathbf{i}}$. As a first step, we sought to identify the extent to which scores on the HBCTSS and MASE scales might vary across the sample. We studied these interactions using Two-ways ANOVA. Finally, we also tested the score on these scales according to other independent variables such as gender and year of birth with One-Way ANOVA.

$\mathbf{R} \mathbf{Q}_{\text {ii }}$ We proceeded to a regression based on the general linear model. A stepwise model selection by Akaike Information Criterion (AIC) was performed, starting with a complete model, and testing the deletion of factors whose loss gives the most statistically insignificant deterioration of the model fit. 
Data were analyzed with RStudio Desktop 1.4.1717 ( $R$ 4.1.1).

\section{Results}

\section{Sample Characteristics}

There are many demographic disparities among cases and countries as we can see in Table 1 about gender: unlike other cases where the male-female ratio is rather balanced, Wallonia vocational training is predominantly male ( $2 / 3$ of respondents). In addition, we note that Quebec preservice teachers work far more than their Wallonian and French counterparts: only $10 \%$ of Quebec preservice teachers don't work in addition to their studies, while the proportion of unemployed preservice teachers is $85.6 \%$ in Wallonia and $74.4 \%$ in France (Table 1 Distribution of Preservice teachers' Gender within Types of Training and Countries

\begin{tabular}{lccccc}
\hline \multirow{2}{*}{ Type of Training } & \multirow{2}{*}{ Gender } & \multicolumn{3}{c}{ Country } & \multirow{2}{*}{ Total } \\
\cline { 3 - 5 } & & Wallonia & France & Quebec & \\
\hline \multirow{2}{*}{ Disciplinary Training } & Men & $49.1 \%$ & $54.4 \%$ & - & $52.7 \%$ \\
& Women & $50.9 \%$ & $44.0 \%$ & - & $46.2 \%$ \\
& Other & & $1.6 \%$ & - & $1.1 \%$ \\
\multirow{5}{*}{ Vocational Training } & Total & $100.0 \%$ & $100.0 \%$ & - & $100.0 \%$ \\
& Men & $66.7 \%$ & - & $50.0 \%$ & $58.7 \%$ \\
& Women & $30.3 \%$ & - & $50.0 \%$ & $39.7 \%$ \\
\multirow{5}{*}{ Total Sample } & Other & $3.0 \%$ & - & & $1.6 \%$ \\
& Total & $100.0 \%$ & - & $100.0 \%$ & $100.0 \%$ \\
& Men & $55.6 \%$ & $54.4 \%$ & $50.0 \%$ & $54.3 \%$ \\
& Women & $43.3 \%$ & $44.0 \%$ & $50.0 \%$ & $44.5 \%$ \\
& Other & $1.1 \%$ & $1.6 \%$ & - & $1.2 \%$ \\
& Total & $100.0 \%$ & $100.0 \%$ & $100.0 \%$ & $100.0 \%$ \\
\hline
\end{tabular}

) .

Finally, preservice teachers in vocational training are slightly older: $68.3 \%$ of preservice teachers in VT are born before 1999 vs. $71.4 \%$ of preservice teachers in DT were born in 1999 or later (Table A1). 
Table 1

Distribution of Preservice teachers' Gender within Types of Training and Countries

\begin{tabular}{lccccc}
\hline \multirow{2}{*}{ Type of Training } & \multirow{2}{*}{ Gender } & \multicolumn{3}{c}{ Country } & \multirow{2}{*}{ Total } \\
\cline { 3 - 5 } & & Wallonia $^{1}$ & France $^{2}$ & Quebec $^{3}$ & \\
\hline Disciplinary Training & Men & $49.1 \%$ & $54.4 \%$ & - & $52.7 \%$ \\
& Women & $50.9 \%$ & $44.0 \%$ & - & $46.2 \%$ \\
& Other & & $1.6 \%$ & - & $1.1 \%$ \\
& Total & $100.0 \%$ & $100.0 \%$ & - & $100.0 \%$ \\
\multirow{5}{*}{ Vocational Training } & Men & $66.7 \%$ & - & $50.0 \%$ & $58.7 \%$ \\
& Women & $30.3 \%$ & - & $50.0 \%$ & $39.7 \%$ \\
& Other & $3.0 \%$ & - & & $1.6 \%$ \\
\multirow{5}{*}{ Total Sample } & Total & $100.0 \%$ & - & $100.0 \%$ & $100.0 \%$ \\
& Men & $55.6 \%$ & $54.4 \%$ & $50.0 \%$ & $54.3 \%$ \\
& Women & $43.3 \%$ & $44.0 \%$ & $50.0 \%$ & $44.5 \%$ \\
& Other & $1.1 \%$ & $1.6 \%$ & - & $1.2 \%$ \\
& Total & $100.0 \%$ & $100.0 \%$ & $100.0 \%$ & $100.0 \%$ \\
\hline
\end{tabular}

Table 2

Distribution of Preservice teachers' Employment within Types of Training and Countries

\begin{tabular}{lccccc}
\hline \multirow{2}{*}{ Type of Training } & \multirow{2}{*}{ Employment } & \multicolumn{3}{c}{ Country } & \multirow{2}{*}{ Total } \\
\cline { 3 - 5 } & & Wallonia & France & Quebec & \\
\hline \multirow{2}{*}{ Disciplinary Training } & $<20 \mathrm{~h} /$ week & $7.0 \%$ & $19.2 \%$ & - & $15.4 \%$ \\
& $\geq 20 \mathrm{~h} /$ week & $1.8 \%$ & $6.4 \%$ & - & $4.9 \%$ \\
& Unemployed & $91.2 \%$ & $74.4 \%$ & - & $79.7 \%$ \\
& Total & $100.0 \%$ & $100.0 \%$ & - & $100.0 \%$ \\
Vocational Training & $<20 \mathrm{~h} /$ week & $24.2 \%$ & - & $70.0 \%$ & $46.0 \%$ \\
& $\geq 20 /$ week & $.0 \%$ & - & $20.0 \%$ & $9.5 \%$ \\
& Unemployed & $75.8 \%$ & - & $10.0 \%$ & $44.4 \%$ \\
\multirow{3}{*}{ Total Sample } & Total & $100.0 \%$ & - & $100.0 \%$ & $100.0 \%$ \\
& $<20 \mathrm{~h} /$ week & $13.3 \%$ & $19.2 \%$ & $70.0 \%$ & $23.3 \%$ \\
& $\geq 20 /$ week & $1.1 \%$ & $6.4 \%$ & $20.0 \%$ & $6.1 \%$ \\
& Unemployed & $85.6 \%$ & $74.4 \%$ & $10.0 \%$ & $70.6 \%$ \\
& Total & $100.0 \%$ & $100.0 \%$ & $100.0 \%$ & $100.0 \%$ \\
\hline
\end{tabular}

\section{$R_{Q_{i}}$. What is the critical thinking skill level of 1st-year preservice teachers and how do they perceive and evaluate their metaliteracy skills?}

An overview of the institution's country. Visually, we can observe that French students have lower scores on critical thinking and metaliteracy self-efficacy scales than their Walloon and, especially, Quebec counterparts (Figure 2). An ANOVA reveals a significant difference in critical thinking skills (HBCTSS) by country, $F(2)=7.47, p=$

1 Actual distribution between women and men at the Université de Namur (DT) was $54.86 \%$ of women and $45,14 \%$ of men $(n=144)$ and distribution at Henallux (VT) was $30.99 \%$ of women and $69.01 \%$ of men (the last reported figures are for the 3 years of the programme).

2 We didn't get any figures from Université Bordeaux-Montaigne.

3 Actual distribution between women and men at the Université de Montréal was 36,67\% of women and $63,33 \%$ of men $(n=30)$. We didn't get any figures from UQAM. 
.001 , the effect size is medium, $\eta_{\mathrm{p}}^{2}=.06$, CI95\% $(.01, .12)$. The difference is significant between France and Quebec (mean difference: -.76; $t[242]=-3.81, p_{\text {holm }}<.001$, the effect size is large, Cohens' $d=-.78$, CI95\% $[-1.18, .37])$ and between Wallonia and Quebec (mean difference: $-.53 ; t[242]=-2.57, p_{\text {holm }}<.022$, the effect size is medium, Cohens' $d=-.54$, CI95\% $[-.96, .12])$.

In terms of metaliteracy self-efficacy, the difference is above the significance level, $F(2)=2.81, p=.062$, the effect size is small, $\eta^{2}=.02$, CI95\% $(.00, .07)$. The difference between France and Quebec is slightly above the significance level (mean difference: $-.48 ; t[242]=-2.37, p_{\text {holm }}=.056$, the effect size is medium, Cohens' $d=-$ .48$, CI95\% $[-.88,-.08])$.
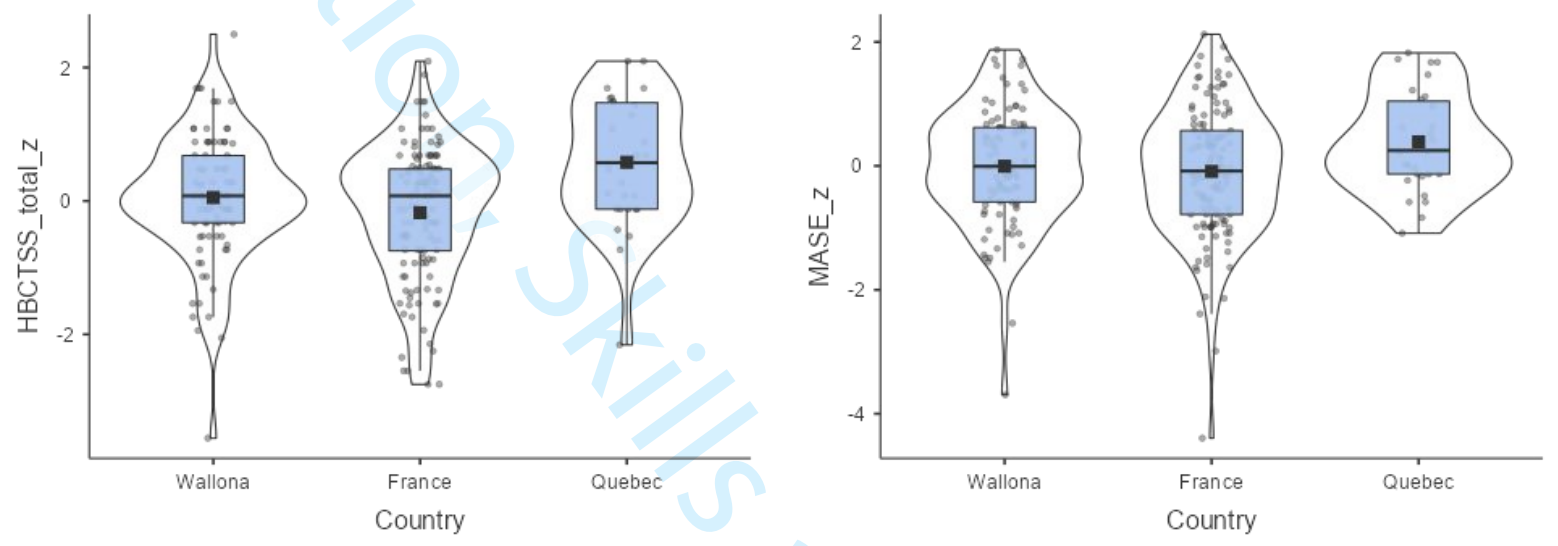

Figure 2. Box plots and violins of standardized HBCTSS (left) and MASE (right) by the institution's country.

An overview of scores by training type. It can also be observed that students in vocational training have very slightly higher scores on critical thinking and metaliteracy self-efficacy scales than their counterparts in disciplinary training (Figure 3). A t-test reveals a non-significant difference in critical thinking skills (HBCTSS) by country, $t(243)=-1.35, p=.179$, the size effect is small, Cohens' $d=$ .20 , CI95\% $(-.48, .09)$. In terms of metaliteracy self-efficacy, the difference is significant, $t(243)=-2.68, p=.008$, the effect size is medium, Cohens' $d=-.39$, CI95\% $(-.68, .10)$. 

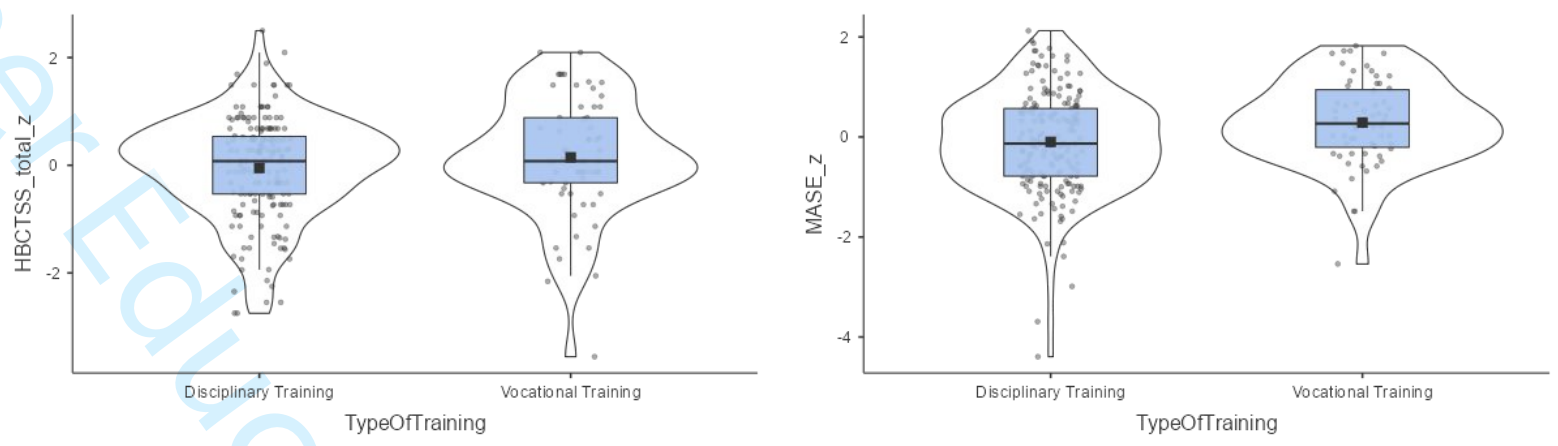

Figure 3. Box plots and violins of standardized HBCTSS (left) and MASE (right) score by type of training.

Interaction between the type of training and likelihood of becoming a teacher. Considering that students in VT believe more that they will become teachers after their studies than their colleagues in disciplinary education $\left(\chi^{2}[3]=44.07, p\right.$ $<.001$; Cramer's $V=.42$ ), we question their combined effect on critical thinking and metaliteracy self-efficacy.

A two-way analysis of variance was conducted on the influence of the two independent variables (type of training and likelihood of becoming a teacher) on HBCTSS. There is no interaction effect, and the main effects are not statistically significant too (Table A2).

Finally, there is no statistically significant interaction effect and main effect on MASE (Table A3). However, there is a significant difference between students considering that it is very likely (7/7) that they will become teachers and students considering that become a teacher is neither likely nor unlikely $(4 / 7)(+.45, C 195 \%$ $[.03, .88], p=.033)$. There is a significant difference between VT students considering that it is very likely (7/7) that they will become teachers and DT students considering that become a teacher is neither likely nor unlikely (4/7) $(+.61, C 195 \%[.00,1.22], p=.048)$.

Interaction between the country of study establishment and employment. There are significant differences in employment between countries $\left(\chi^{2}[4]=64.72, p\right.$ $<.001$; Cramer's $V=.36$ ), for example, students in Quebec work more than in France or Wallonia. Thus, we also question their combined effect on critical thinking and metaliteracy self-efficacy.

A two-way analysis of variance was conducted on the influence of the two independent variables (country of study and employment) on HBCTSS (Table A4). The interaction effect is just above the threshold of

significance, $F(4,236)=2.23, p=.066$, with large effect $\eta_{\mathrm{g}}^{2}=.04$, CI95\% (.00, .08). The difference between students working less than 20h/week students in Quebec and unemployed students in France is significant (+.86, C195\%[.13, 1.59], $p=.009)$. There is also a significant difference between Quebec and French students working less than 20h/week (+1.06, C195\%[.15, 1.96], $p=.009)$.

The main effects are significant. The main effect of the country of study yields an $F$ ratio of $F(2,236)=4.20, p=.016, \eta_{g}^{2}=.03$, CI95\% $(.00, .08)$, and the main effect 
for employment yields an $F$ ratio of $F(2,236)=3.57, p=.030, \eta_{g}^{2}=.03$, CI95\% $(.00$, $.08)$.

Finally, there is no statistically significant difference in the two-way analysis of variance done on MASE (Table A5). There is no interaction effect, and the main effect of the country is not statistically significant. The main effect for employment is at the significant threshold, $F(2,236)=2.71, p=.068$, with a small effect $\eta_{g}^{2}=.02, C 195 \%(.00, .07)$.

About gender and age. Even if the main effects are above the standard significance threshold, with negligible effects (HBCTSS: $F[2,242]=.70, p=.498$, $\eta_{p}^{2}=.01, C 195 \%[.00, .03]$; MASE: $F[2,242]=1.22, p=.297, \eta_{p}^{2}=.01, C 195 \%[.00$, $.04]$ ), we identified gender differences in average. Men have higher metaliteracy selfefficacy levels than women (MASE: $+.19, p_{\text {tukey }}=.289$ ) and slightly higher critical thinking scores (HBCTSS: $\left.+.15, p_{\text {tukey }}=.475\right)$. Main effects of the year of birth are above the standard significance threshold too, with very small effects (HBCTSS: F[7, $237]=1.97, p=.059, \eta_{p}^{2}=.06, C 195 \%[.00, .09]$; MASE: $\mathrm{F}[7,237]=1.73, p=.103$, $\left.\eta_{p}^{2}=.05, C 195 \%[.00, .08]\right)$ : pairwise comparisons reveal small differences that are not significant.

\section{$\mathrm{RQ}_{\mathrm{ii}}$ Is Metaliteracy self-efficacy a good predictor of critical thinking skills or is the potential gap among preservice teachers the fruit of other characteristics?}

The correlation between the HBCTSS and the MASE was examined. A weak positive but significant correlation between critical thinking skills and metaliteracy selfefficacy can be observed, $r(243)=.23, p<.001$, CI95\% $(.10, .34)$. If we examine the correlation with the factors composing the HBCTSS (Figure 3), a weak positive correlation is identified for only two of them, the factor "Thinking as hypothesis testing" (above the significance level, $\rho=.11, p=.079$ ) and the "Decision-making and problem-solving" factor (significant, $\rho=.28, p<.001$ ). For the three other factors of the HBCTSS, the correlation with the MASE is almost zero $(\rho \simeq 0)$. 


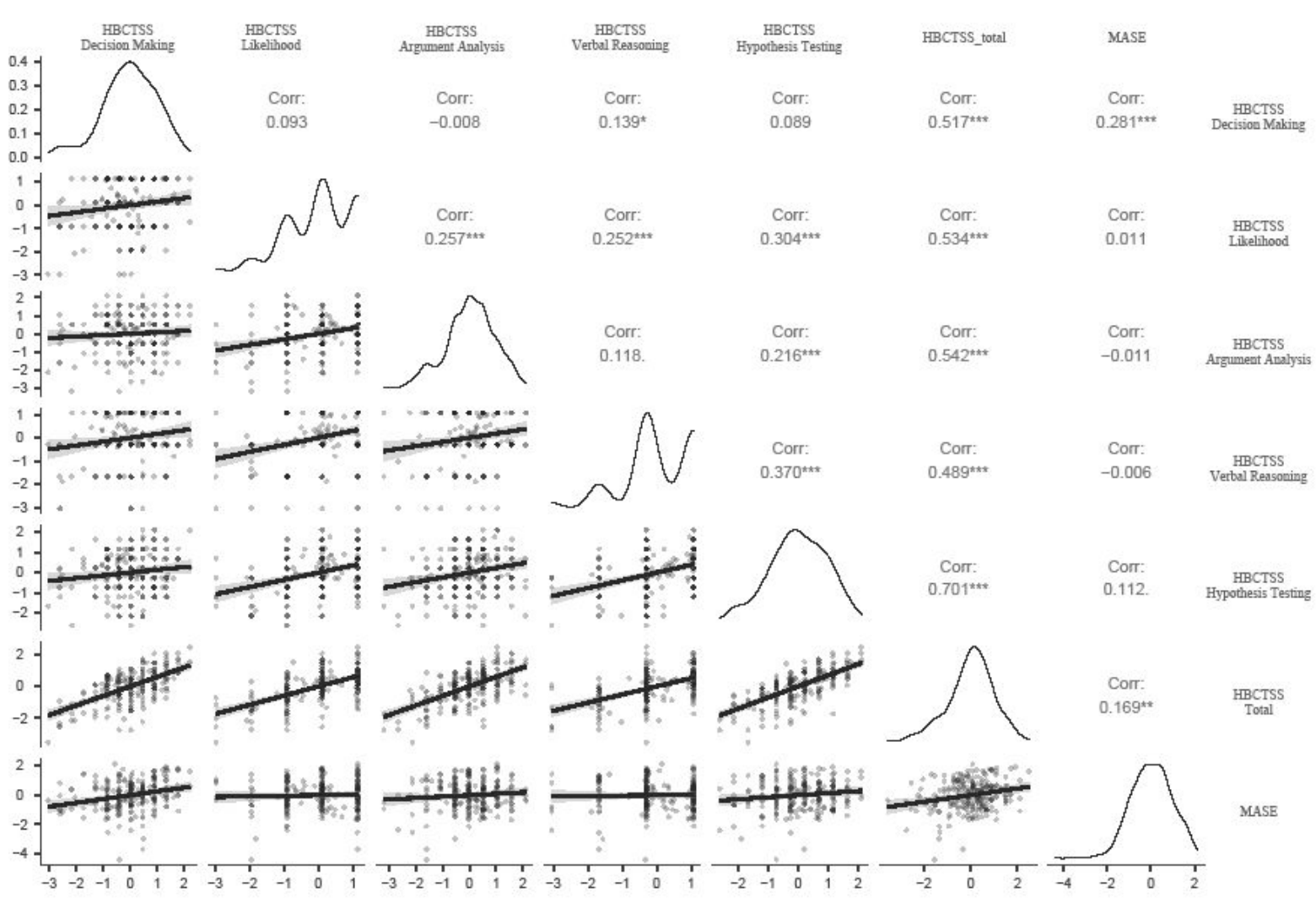

Figure 2. Spearman correlation matrix between MASE, and HBCTS, and its different factors

We tried to develop a model to investigate the factors influencing critical thinking skills, based on metaliteracy self-efficacy and the qualitative variables already mentioned. We did a backward elimination stepwise regression based on AIC. The best model to predict HBCTSS should be the one including metaliteracy self-efficacy, type of training, and country of study, with $A I C=-22.41$. The results of the regression indicate that the model is a significant predictor of critical thinking skills score $(\mathrm{HBCTSS}), F(4,240)=8.21, p<.001$. This model explains $12 \%\left(R^{2}=.120\right)$ of the variance (Table A6).

MASE, type of training, and country of study have significant effects (respectively $F[1,240]=11.74, p<.001 ; \quad F[1,240]=6.73, p=.010 ; \quad F[2$, $240]=9.06, p<.001)$. The score for disciplinary training students is greater than the score for vocational training students by about $1 / 2$ standard deviation $(+.54$, CI95\% [.13, .95]). The score of Wallonia students is lower than that of their Quebec counterpart by almost one standard deviation (-.79, CI95\% [-1,26, -.32]). Between students in France and Quebec, this difference exceeds the one standard deviation $(-1.19$, CI95\%[-1.26, $.32])$.

\section{Discussion}

The main objective of this research was to describe the level of preservice teachers in critical thinking skills (HBCTSS), and metaliteracy self-efficacy (MASE) in three French-speaking nations. 
Is training or employment the most important factor? In terms of critical thinking differences by the type of training, significant differences could be identified between preservice teachers in disciplinary training and vocational training. Students in the latter are getting higher average scores. Though, our results are ambiguous since it is Quebec training that has a positive influence. The relationship with employment, however, complex it may be to grasp, could explain part of our modeling: working while studying and the anticipation of becoming a teacher have positive impacts and metaliteracy self-efficacy.

The idea that vocational training would be positive for critical thinking skills and dispositions is also supported by the already mentioned Fong and Kim metaanalysis (2017). The authors assume that critical thinking is more relevant to the success of students in vocational training, especially in nursing where clinical reasoning is central. However, beyond the comparison of averages, our modeling rather tends to show that the role of vocational training on critical thinking skills is negative and that it is more the fact of studying in Quebec that would positively influence critical thinking skills. Yet, we hypothesize that it may not be so much the place of education that comes into play as the fact that preservice teachers in Quebec have a more active working life, and potentially in a para-educational context. The ANOVA factorial design showed that significant differences were identified according to the country and the time students worked. It has already been suggested that students working longer hours off-campus and juggling professional responsibilities had to maintain skills in time management, self-discipline, etc., leading to attitudes and skills conducive to high levels of critical thinking (Terenzini et al., 1996). As reported in our data, Quebec students are more likely to work more than their Walloon or French counterparts: in 2011, 42.3\% of fulltime Quebec students worked during study sessions and at least 15 hours per week (Gauthier and Labrie, 2013). Among the compared OECD countries, Canada is the country with the highest proportion of students aged 15 to 24 receiving incomes from work $(76.66 \%)$ and Belgium the second lowest $(4.27 \%)$, while France $(35.41 \%)$ is slightly below the OECD average (37.62\%) (OCDE, 2017).

As for the likelihood of getting a job, it was already known that the type of job anticipated was a partial predictor of critical thinking dispositions (Rudd \& Moore, 2003). However, it is probably not so much the anticipation of the type of job that is important as the motivation that results from the involvement in vocational training. To explain this, we can refer to motivation and social cognitive theory (Bandura, 1986). The learner's goals and motivation influence his or her efforts, both qualitatively and quantitatively, and his or her level of commitment. For example, a learner with high expectations, particularly because of his or her sense of self-efficacy and expectations (in this case, regarding his or her career goal), would be better able to set high goals, engage in an activity, or even persevere and deploy appropriate cognitive and metacognitive strategies, which are required for critical thinking.

For further research, we first recommend that further methodological work should be done to study the validity and reliability of the French language instruments used in this research. Then, it would be useful to look at the role of the professional context (vocational or non-vocational training, employment outside of school, internships, etc.) to identify more precisely its role in self-efficacy and critical thinking, by asking the following questions: Do students' professional activities and internships 
contribute to critical thinking and, if so, in what way? If involvement in training with a strong professionalizing dimension helps to strengthen critical thinking dispositions and skills, how does this translate during training (courses, internships, etc.)? Mediation and moderation studies would help to answer this question. Finally, we suggest continuing this work in order to identify exogenous and endogenous variables that would strengthen the suggested model, particularly outside of teacher education programs.

Metaliteracy self-efficacy is an important variable on critical thinking skills but rather limited. The data collected highlighted the importance of the type of training and the country of study on the critical thinking skills score. Also, the correlation study and modeling suggest that metaliteracy self-efficacy influences critical thinking skills. While self-efficacy beliefs are generally considered to be predictive of outcomes, here this role appears to be angled and rather marginal.

These results, though showing a weak positive relationship, argue, on the conceptual level, for a better combination between information, digital or media literacy, and critical thinking. Links between critical thinking disposition and information literacy were already known (Çiçek Sağlam et al., 2017), as well as media literacy being an important predictor of critical thinking disposition (Karaman, 2016). Conceptually, the results call for bringing metaliteracy (and all literacies) even closer to critical thinking. The conceptualization of critical thinking developed before the digital age and the ensuing informational revolution could be reworked to include literacy dispositions and skills.

Then, at the educational level, the link between critical thinking skills and literacies (whether metaliteracy or not) should be reinforced, as students need to mobilize strategies for filtering information from the Internet. Because of the removal of traditional intermediaries (teachers, scholars, etc.), young people now have the responsibility to detect reliable information. This would strengthen the operationalization of critical thinking and promote a better contextualization of scenarios used to quantify critical thinking. Initiatives such as the Quebec government's Digital Competency Framework (Ministère de l'Éducation et de l'Enseignement supérieur, 2019) are already contributing to bridging the gap between digital and informational skills and critical thinking, regardless of grade levels and whether one is a teacher or a learner. To take advantage of this, a teacher's training in technologies that is not only procedural is essential: not only should they know how to handle this or that technology, but they also need to understand the dynamics of the digital ecosystem in its many dimensions. Mirroring this, awareness-raising among learners is essential, in an interdisciplinary approach. Thus, one might imagine a disciplinary reflexive activity, requiring the use of information literacy strategies (what resources did I use, what did I do, etc.) and during which the student will have to describe (e.g., in a research diary) the procedures used, and the analysis strategies mobilized (How did I analyze and confront arguments? Why did I make one decision over another? What assumptions did I consider? etc.), to develop their final argumentation.

We suggest conducting studies on the place of metaliteracy and literacy on critical thinking scales. Given this conceptual shift, these studies would help answer the following questions: do metaliteracy dispositions, including self-efficacy, contribute to a better understanding of critical thinking dispositions? Does the assessment of 
metaliteracy skills more accurately quantify critical thinking skills? Are critical thinking dispositions and skills mobilized differently in traditional and informationintensive contexts, especially on the Internet?

To go further, the current health context highlighted the importance of the subject and the need to link literacy and critical thinking. Brungard and Klucevsek (2019) suggested that metaliteracy and its four domains of intervention can be used to develop learners' scientific literacy. To us, this objective becomes critical in the context of the COVID-19 pandemic and because of the "infodemic" phenomena (Cinelli et al., 2020; Monnier, 2020; Orso et al., 2020): e.g., according to Dib et al. (2021), a sort of metaliteracy (called "eHealth literacy") is necessary to navigate on "the web in search for health information and processing the one encountered through social media" (Dib et al., 2021, p. 2). However, the subject must not lead us to fall into Manichaeism: Cooke (2021) suggests a right to be misinformed, while emphasizing the necessity of further literacy training.

\section{Limitations}

The fact that samples in vocational training are much smaller than samples in disciplinary training may introduce a quantification bias. Since vocational training favors smaller class groups, further research will have to expand the samples. Besides, our research was conducted on a non-probabilistic convenience sample which introduces another sampling bias.

Regarding external validation, as a case study objective was not to generalize the results (Yin, 2006), we have to keep in mind that this research was conducted in a limited number of cases.

Finally, the research was conducted among the specific population of preservice teachers in history, which may induce a bias and limits the generalizability of the results.

\section{Conclusion}

We were able to expose several differences related to metaliteracy self-efficacy and critical thinking skills for preservice teachers. Although gender is sometimes considered as an explanatory factor, such differences were not identified. However, important differences were identified according to the country of study and the type of training.

We proposed a model that contributes to partially explain the level of critical thinking skills. It includes four factors: country of study, type of training, and metaliteracy self-efficacy. Metaliteracy self-efficacy plays a more important role, which should bring up questions about the role of metaliteracy (and other literacies) for further research. More importantly, this opens the door to conceptual thinking aimed at bringing closer literacies and critical thinking. However, the effectiveness of this model is limited, explaining only about $12 \%$ of the total variance in critical thinking skills.

Thus, although differences can be analyzed in terms of national or educational specificities, we rather question the weight of the professional context of these results. Even if factors related to professional expectations and extracurricular employment 
were excluded from the modeling for parsimony reasons, we note that, in Quebec, the proportion of preservice teachers who work is high and that working seems to have a positive effect on metaliteracy self-efficacy. Logically enough, we also note a greater propensity to project oneself into a specific professional goal among students in vocational training; the likelihood of becoming a teacher at the end of the training is positively correlated to critical thinking skills, self-efficacy in critical thinking, and selfefficacy in metaliteracy assessment. Further research could favorably question the role of professional and educational context as environmental factors capable of influencing informational literacies and critical thinking in terms of dispositions and skills. 


\section{References}

ACRL. (2016), Framework for Information Literacy for Higher Education, American Library Association, Chicago, IL, available at: https://web.archive.org/web/20200801140410/http://www.ala.org/acrl/standar ds/ilframework (accessed 10 October 2017).

Bandura, A. (1986), Social Foundations of Thought and Action: A Social Cognitive Theory, Prentice-Hall, Englewood Cliffs, NJ.

Blair, J.A. (2012), "The Keegstra Affair: A Test Case for Critical Thinking”, in Blair, J.A. and Tindale, C.W. (Eds.), Groundwork in the Theory of Argumentation: Selected Papers of J. Anthony Blair, Springer Netherlands, Dordrecht, PaysBas, pp. 13-22.

Brungard, A.B. and Klucevsek, K. (2019), “Constructing Scientific Literacy Through Metaliteracy", in Mackey, T.P. and Jacobson, T.E. (Eds.), Metaliterate Learning for the Post-Truth World, ALA Neal-Schuman, Chicago, IL, pp. 81102.

Butler, H.A. (2012), "Halpern Critical Thinking Assessment Predicts Real-World Outcomes of Critical Thinking”, Applied Cognitive Psychology, Vol. 26 No. 5, pp. $721-729$.

Butler, H.A. and Halpern, D.F. (2020), “Critical Thinking Impacts Our Everyday Lives”, Critical Thinking in Psychology, 2nd edition. Cambridge University Press, Cambridge, Royaume-Uni, pp. 152-172.

Çiçek Sağlam, A., Çankaya, İ., Üçer, H. and Çetin, M. (2017), “The Effect of Information Literacy on Teachers' Critical Thinking Disposition", Journal of Education and Learning, Vol. 6 No. 3, p. 31. 
Cinelli, M., Quattrociocchi, W., Galeazzi, A., Valensise, C. M., Brugnoli, E., Schmidt, A. L., Zola, P., et al. (2020), “The COVID-19 Social Media Infodemic”, 10 March, available at: http://arxiv.org/abs/2003.05004 (accessed 1 August 2020).

Cooke, N.A. (2021), “A Right to be Misinformed? Considering Fake News as a Form of Information Poverty”, in Greene Taylor, N., Kettnich, K., Gorham, U. and T. Jaeger, P. (Eds.), Libraries and the Global Retreat of Democracy: Confronting Polarization, Misinformation, and Suppression, Vol. 50, Emerald Publishing Limited, pp. 45-60.

Desfriches Doria, O. (2018), “Culture informationnelle et pensée critique, vers une approche créative", Journal for Communication Studies, Vol. 11 No. 2, pp. $107-129$.

Dib, F., Mayaud, P., Chauvin, P. and Launay, O. (2021), “Online mis/disinformation and vaccine hesitancy in the era of COVID-19: Why we need an eHealth literacy revolution”, Human Vaccines \& Immunotherapeutics, Taylor \& Francis, pp. 13.

Ennis, R.H. (1996), “Critical Thinking Dispositions: Their Nature and Assessability”, Informal Logic, Vol. 18 No. 2, pp. 165-182.

Ennis, R.H. and Scott, G. (2018), “An Annotated List of English-Language Critical Thinking Tests”, April, available at: https://web.archive.org/web/20200801182858/http://criticalthinking.net/wpcontent/uploads/2019/02/An-Annotated-List-of-English-Language-CriticalThinking-Tests.pdf.

Eysenbach, G. (2007), "From Intermediation to Disintermediation and Apomediation: New Models for Consumers to Access and Assess the Credibility of Health 
Information in the Age of Web 2. 0", Studies in Health Technology and Informatics, Vol. 129 No. 1, pp. 162-169.

Facione, P. A. (1990), Critical Thinking: A Statement of Expert Consensus for Purposes of Educational Assessment and Instruction, Research Findings and Recommendations, American Philosophical Association, Newark, DEL, p. 112. Fong, C.J., Kim, Y., Davis, C.W., Hoang, T. and Kim, Y.W. (2017), “A Meta-Analysis on Critical Thinking and Community College Student Achievement", Thinking Skills and Creativity, Vol. 26 No. Supplement C, pp. 71-83.

Gauthier, M.-A. and Labrie, M.-P. (2013), “Données sociodémographiques en bref”, Institut de la Statistique du Québec, Vol. 17 No. 2, available at: https://web.archive.org/web/20181206211117/http://www.stat.gouv.qc.ca///sta tistiques/conditions-vie-societe/bulletins/sociodemo-vol17-no2.pdf (accessed 1 April 2020).

Georgiadou, E., Rahanu, H., Siakas, K.V., McGuinness, C., Edwards, J.A., Hill, V., Khan, N., et al. (2018), "Fake News and Critical Thinking in Information Evaluation”, Proceedings International Scientific Conference “Western Balkan Information Literacy": Alternative Facts, Fake News, Getting to the Truth with Information Literacy, presented at the WBILC 2018, Bihac, BosniaHerzegovina, pp. 50-71.

Halpern, D.F. (1998), “Teaching Critical Thinking for Transfer Across Domains: Disposition, Skills, Structure Training, and Metacognitive Monitoring", American Psychologist, Vol. 53 No. 4, pp. 449-455.

Halpern, D. F. (2016), Manual, Halpern Critical Tool Assessment, version 51, revision 1, Schuhfried GmbH, Mödling, Autriche, available at: https://web.archive.org/web/20200801211320/https://doc-10-48- 
docs.googleusercontent.com/docs/securesc/ha0ro937gcuc717deffksulhg5h7mb p1/2jc4dsu45pckg2hoap17sm9vlhkbuhpb/1596316350000/015067809908031 01185/*/0BzUoP_pmwylgdEpCR05PeW9qUzA?e=download (accessed 3 April 2017).

Hitchcock, D. (2018), "Critical Thinking”, in Zalta, E.N. (Ed.), The Stanford Encyclopedia of Philosophy, Fall 2018. The Metaphysics Research Lab Center for the Study of Language and Information, Stanford University, Stanford, CA, available at: https://plato.stanford.edu/archives/fall2018/entries/criticalthinking/ (accessed 27 August 2019).

Hollis, H. (2019), “Information Literacy and Critical Thinking: Different Concepts, Shared Conceptions", Proceedings, presented at the Tenth International Conference on Conceptions of Library and Information Science, Ljubljana, Slovenia, available at: http://informationr.net/ir/24-4/colis/colis1921.html (accessed 21 August 2019).

Jacobson, T. and Mackey, T. (2013), "Proposing a Metaliteracy Model to Redefine Information Literacy", Comminfolit, Vol. 7 No. 2, pp. 84-91.

Karaman, M.K. (2016), “Öğretmen Adaylarının Medya Okuryazarlık Düzeyleri ve Eleştirel Düşünme Eğilimleri Üzerine Bir Araştırma”, Gümüşhane Üniversitesi Illetişim Fakültesi Elektronik Dergisi, Vol. 4 No. 1, pp. 326-350.

Kurbanoglu, S.S. (2003), "Self-Efficacy: A Concept Closely Linked to Information Literacy and Lifelong Learning”, Journal of Documentation, Vol. 59 No. 6, pp. $635-646$.

Kurbanoglu, S.S., Akkoyunlu, B. and Umay, A. (2006), "Developing the Information Literacy Self-Efficacy Scale", Journal of Documentation, Vol. 62 No. 6, pp. $730-743$. 
van Laar, E., van Deursen, A.J.A.M., van Dijk, J.A.G.M. and de Haan, J. (2017), “The Relation Between 21st-Century Skills and Digital Skills: A Systematic Literature Review”, Computers in Human Behavior, Vol. 72, pp. 577-588.

Mackey, T. and Jacobson, T. (2011), "Reframing Information Literacy as a Metaliteracy", College Research Libraries, Vol. 72 No. 1, pp. 62-78.

Mackey, T. and Jacobson, T. (2018), "Goals and Learning Objectives", Metaliteracy.Org, 11 April, available at: https://metaliteracy.org/learningobjectives/ (accessed 13 April 2018).

Mackey, T.P. (2019), "Empowering Metaliterate Learners for the Post-Truth World”, in Mackey, T.P. and Jacobson, T.E. (Eds.), Metaliterate Learning for the PostTruth World, ALA Neal-Schuman, Chicago, IL, pp. 1-32.

Marzal, M. Á. and Martínez-Cardama, S. (2020), "Clasificación de la investigación académica en Metaliteracy”, Revista Española de Documentación Científica, Vol. 43 No. 4, pp. e279-e279.

McPeck, J.E. (1981), Critical Thinking and Education, Martin Robertson, Oxford, Royaume-Uni.

Ministère de l'Éducation et de l'Enseignement supérieur. (2019), Digital Competency Framework, Gouvernement du Québec, Québec, Québec, available at: http://www.education.gouv.qc.ca/fileadmin/site_web/documents/ministere/Ca dre-reference-competence-num-AN.pdf.

Mohamed, S. (2019), "A Critical Praxis in the Information Literacy Education Classroom Using the ACRL Framework for Information Literacy for Higher Education”, in Kurbanoğlu, S., Špiranec, S., Ünal, Y., Boustany, J., Huotari, M.L., Grassian, E., Mizrachi, D., et al. (Eds.), Information Literacy in Everyday 
Life, presented at the ECIL 2018, Springer International Publishing, Oulu, Finland, pp. 506-521.

Monnier, A. (2020), “COVID-19 : de la pandémie à l'infodémie et la chasse aux fake news", Recherches \& éducations, Société Binet Simon, No. HS, available at: http://journals.openedition.org/rechercheseducations/9898 (accessed 1 August 2020).

OCDE. (2017), Education at a Glance 2017: OECD Indicators, Organisation de coopération et de développement économiques, Paris, France, available at:https://doi.org/10.1787/eag-2017-en.

Orso, D., Federici, N., Copetti, R., Vetrugno, L. and Bove, T. (2020), “Infodemic and the Spread of Fake News in the COVID-19-Era", European Journal of Emergency Medicine, available at:https://doi.org/10/gg4q9d.

Pochet, B. (2016), “Évaluation des compétences informationnelles des étudiants : trois enquêtes, un même constat".

van Prooijen, J.-W. (2017), "Why Education Predicts Decreased Belief in Conspiracy Theories", Applied Cognitive Psychology, Vol. 31 No. 1, pp. 50-58.

Puig, B., Blanco-Anaya, P. and Pérez-Maceira, J. J. (2021), “'Fake News' or Real Science? Critical Thinking to Assess Information on COVID-19”, Frontiers in Education, Vol. 6, p. 92.

Špiranec, S. (2014), "Information Literacy in Web 2.0 Environments: Emerging Dimensions of Research", Libellarium : Journal for the History of Writing, Books and Memory Institutions, Vol. 7 No. 1, pp. 55-72.

Tang, Y. and Tseng, H.W. (2013), “Distance Learners' Self-Efficacy and Information Literacy Skills", The Journal of Academic Librarianship, Vol. 39 No. 6, pp. $517-521$. 
Terenzini, P.T., Springer, L., Yaeger, P.M., Pascarella, E.T. and Nora, A. (1996), "FirstGeneration College Students: Characteristics, Experiences, and Cognitive Development”, Research in Higher Education, Vol. 37 No. 1, pp. 1-22.

Vallerand, R.J. (1989), "Vers une méthodologie de validation transculturelle de questionnaires psychologiques: implications pour la recherche en langue française", Canadian Psychology, Vol. $30 \quad$ No. 4, available at:https://doi.org/10/d3qc6k.

Verburgh, A., François, S., Elen, J. and Janssen, R. (2013), “The Assessment of Critical Thinking Critically Assessed in Higher Education: A Validation Study of the CCTT and the HCTA”, Education Research International, Vol. 2013, pp. 1-13. Yin, R.K. (2006), “Case Study Methods”, in Green, J.L., Camilli, G. and Elmore, P.B. (Eds.), Handbook of Complementary Methods in Education Research, Lawrence Erlbaum Associates, Mahwah, NJ, pp. 111-122. 


\section{Appendices}

Table A1

Distribution of Preservice teachers by type of training and year of birth

\begin{tabular}{|c|c|c|c|c|}
\hline Year of birth & & $\begin{array}{c}\text { Disciplinary } \\
\text { Training } \\
\end{array}$ & $\begin{array}{c}\text { Vocational } \\
\text { Training } \\
\end{array}$ & Total \\
\hline \multirow[t]{3}{*}{1975 to 1979} & Observed & 2 & 3 & 5 \\
\hline & Expected & 3.71 & 1.29 & 5.00 \\
\hline & $\%$ within column & $1 \%$ & $5 \%$ & $2 \%$ \\
\hline \multirow[t]{3}{*}{1980 to 1984} & Observed & 0 & 1 & 1 \\
\hline & Expected & 0.74 & 0.26 & 1.00 \\
\hline & \% within column & $0 \%$ & $2 \%$ & $0 \%$ \\
\hline \multirow[t]{3}{*}{1985 to 1989} & Observed & 3 & 1 & 4 \\
\hline & Expected & 2.97 & 1.03 & 4.00 \\
\hline & $\%$ within column & $2 \%$ & $2 \%$ & $2 \%$ \\
\hline \multirow[t]{3}{*}{1990 to 1994} & Observed & 2 & 7 & 9 \\
\hline & Expected & 6.69 & 2.31 & 9.00 \\
\hline & $\%$ within column & $1 \%$ & $11 \%$ & $4 \%$ \\
\hline \multirow[t]{3}{*}{1995 to 1997} & Observed & 19 & 13 & 32 \\
\hline & Expected & 23.77 & 8.23 & 32.00 \\
\hline & $\%$ within column & $10 \%$ & $21 \%$ & $13 \%$ \\
\hline \multirow[t]{3}{*}{1998} & Observed & 26 & 18 & 44 \\
\hline & Expected & 32.69 & 11.31 & 44.00 \\
\hline & $\%$ within column & $14 \%$ & $29 \%$ & $18 \%$ \\
\hline \multirow[t]{3}{*}{1999} & Observed & 45 & 14 & 59 \\
\hline & Expected & 43.83 & 15.17 & 59.00 \\
\hline & $\%$ within column & $25 \%$ & $22 \%$ & $24 \%$ \\
\hline \multirow[t]{3}{*}{2000} & Observed & 85 & 6 & 91 \\
\hline & Expected & 67.60 & 23.40 & 91.00 \\
\hline & $\%$ within column & $47 \%$ & $10 \%$ & $37 \%$ \\
\hline \multirow[t]{3}{*}{ Total } & Observed & 182 & 63 & 245 \\
\hline & Expected & 182.00 & 63.00 & 245.00 \\
\hline & $\%$ within column & $100 \%$ & $100 \%$ & $100 \%$ \\
\hline
\end{tabular}


Table A2

Two-way ANOVA result using HBCTSS as the criterion and type of training and likelihood of becoming a teacher as predictors

\begin{tabular}{lccccccc}
\hline Predictor & $\boldsymbol{d} \boldsymbol{f}_{\text {num }}$ & $\boldsymbol{d} \boldsymbol{f}_{\text {den }}$ & $\boldsymbol{S S}_{\text {num }}$ & $\boldsymbol{S S}_{\text {den }}$ & $\boldsymbol{F}$ & $\boldsymbol{p}$ & $\boldsymbol{\eta}^{\mathbf{2}}$ \\
\hline (Intercept) & 1 & 237 & .05 & 241.51 & .05 & .820 & .00 \\
& & & & & & & {$[.00, .02]$} \\
Type of training & 1 & 237 & .45 & 241.51 & .44 & .506 & .00 \\
& & & & & & & {$[.00, .03]$} \\
Teaching likelihood & 3 & 237 & .39 & 241.51 & .13 & .944 & .00 \\
Type of training $\times$ Teaching likelihood & 3 & 237 & .40 & 241.51 & .13 & .941 & {$[.00, .00]$} \\
& & & & & & & {$[.00, .00]$} \\
\hline
\end{tabular}

Note. $d f_{\text {num }}$ indicates degrees of freedom numerator. $d f_{\text {den }}$ indicates degrees of freedom denominator. $S S_{\text {num }}$ indicates sum of squares numerator. $S S_{\text {den }}$ indicates sum of squares denominator. $\eta^{2}$ indicates generalized eta-squared. Values in square brackets indicate the $95 \%$ confidence interval $^{4}$.

\section{Table A3}

Two-way ANOVA result using MASE as the criterion and type of training and likelihood of becoming a teacher as predictors

\begin{tabular}{|c|c|c|c|c|c|c|c|}
\hline Predictor & $d f_{\text {num }}$ & $d f_{\text {den }}$ & $S S_{\text {num }}$ & $S S_{\mathrm{den}}$ & $F$ & $p$ & $\eta^{2}$ \\
\hline (Intercept) & 1 & 237 & .00 & 232.63 & .00 & .987 & $\begin{array}{c}.00 \\
{[.00,1.00]}\end{array}$ \\
\hline Type of training & 1 & 237 & .63 & 232.63 & .64 & .423 & $\begin{array}{c}.00 \\
{[.00, .03]}\end{array}$ \\
\hline ProbTeaching & 3 & 237 & 3.34 & 232.63 & 1.13 & .336 & $\begin{array}{c}.01 \\
{[.00, .05]}\end{array}$ \\
\hline Type of training $\times$ Teaching likelihood & 3 & 237 & 1.01 & 232.63 & .34 & .795 & $\begin{array}{c}.00 \\
{[.00, .02]}\end{array}$ \\
\hline
\end{tabular}

Note. $d f_{\text {num }}$ indicates degrees of freedom numerator. $d f_{\text {den }}$ indicates degrees of freedom denominator. $S S_{\text {num }}$ indicates sum of squares numerator. $S S_{\text {den }}$ indicates sum of squares denominator. $\eta^{2}$ indicates generalized eta-squared. Values in square brackets indicate the $95 \%$ confidence interval.

4 For partial eta-squared a confidence level of .90 is generally used rather than .95 


\section{Table A4}

Two-way ANOVA result using HBCTSS as the criterion and country of study and employment (weekly working time) as predictors

\begin{tabular}{lccccccc}
\hline Predictor & $\mathbf{d f}_{\text {num }}$ & $\mathbf{d f}_{\text {den }}$ & $\mathbf{S S}_{\mathbf{n u m}}$ & $\mathbf{S S}_{\mathbf{d e n}}$ & $\mathbf{F}$ & $\mathbf{p}$ & $\mathbf{\eta}^{\mathbf{2}}$ \\
\hline (Intercept) & 1 & 236 & 5.15 & 220.02 & 5.52 & .020 & .02 \\
Country & & & & & & & {$[.00, .07]$} \\
& 2 & 236 & 7.82 & 220.02 & 4.20 & .016 & .03 \\
Employment & 2 & 236 & 6.65 & 220.02 & 3.57 & .030 & {$[.00, .08]$} \\
Country $\times$ Employment & 4 & 236 & 8.33 & 220.02 & 2.23 & .066 & {$[.00, .08]$} \\
& & & & & & & {$[.00, .08]$} \\
\hline
\end{tabular}

Note. $d f_{\text {num }}$ indicates degrees of freedom numerator. $d f_{\text {den }}$ indicates degrees of freedom denominator. $S S_{\text {num }}$ indicates sum of squares numerator. $S S_{\text {den }}$ indicates sum of squares denominator. $\eta^{2}$ indicates generalized eta-squared. Values in square brackets indicate the $90 \%$ confidence interval.

\section{Table A5}

Two-way ANOVA result using MASE as the criterion and country of study and employment (weekly working time) as predictors

\begin{tabular}{llllllll}
\hline Predictor & $\boldsymbol{d} \boldsymbol{f}_{\text {num }}$ & $\boldsymbol{d} \boldsymbol{f}_{\text {den }}$ & $\boldsymbol{S \boldsymbol { S } _ { \text { num } }}$ & $\boldsymbol{S \boldsymbol { S } _ { \text { den } }}$ & $\boldsymbol{F}$ & $\boldsymbol{p}$ & $\boldsymbol{\eta}^{\mathbf{2}}$ \\
\hline (Intercept) & 1 & 236 & 7.72 & 228.74 & 7.97 & .005 & .03 \\
& & & & & & & {$[.00, .09]$} \\
Country & 2 & 236 & 3.70 & 228.74 & 1.91 & .150 & .02 \\
& & & & & & & {$[.00, .06]$} \\
Employment & 2 & 236 & 5.26 & 228.74 & 2.71 & .068 & .02 \\
& & & & & & & {$[.00, .07]$} \\
Country $\times$ Employment & 4 & 236 & 3.01 & 228.74 & .78 & .541 & .01 \\
& & & & & & & {$[.00, .04]$} \\
\hline
\end{tabular}

Note. $d f_{\text {num }}$ indicates degrees of freedom numerator. $d f_{\text {den }}$ indicates degrees of freedom denominator. $S S_{\text {num }}$ indicates sum of squares numerator. $S S_{\text {den }}$ indicates sum of squares denominator. $\eta^{2}$ indicates generalized eta-squared. Values in square brackets indicate the $90 \%$ confidence interval.

Table A6

Regression results using HBCTSS as the criterion

\begin{tabular}{|c|c|c|c|c|c|c|c|}
\hline & \multirow{2}{*}{ Est. } & \multicolumn{2}{|c|}{$95 \% C I$} & \multirow{2}{*}{$t$ val. } & \multirow{2}{*}{$p$} & \multirow{2}{*}{$V I F$} & \multirow{2}{*}{ Partial $r$} \\
\hline & & Lower & Upper & & & & \\
\hline$(\text { Intercept })^{\mathrm{a}}$ & .50 & .15 & .84 & 2.86 & .005 & & \\
\hline MASE & .21 & .09 & .33 & 3.43 & .001 & 1.03 & .22 \\
\hline \multicolumn{8}{|l|}{ TypeOfTraining } \\
\hline$D T$ & .54 & .13 & .95 & 2.60 & .010 & 2.26 & .17 \\
\hline \multicolumn{8}{|l|}{ Country: } \\
\hline Wallonia & -.79 & -1.26 & -.32 & -3.29 & .001 & 2.25 & -.21 \\
\hline France & -1.19 & -1.75 & -.64 & -4.23 & .000 & 2.25 & -.26 \\
\hline
\end{tabular}

Note. aRepresents reference level (levels Quebec, and Vocational training). 